\title{
Language ownership in multilingual settings: Exploring attitudes among students entering the University of KwaZulu-Natal through the Access Program
}

\author{
Andrea Parmegiani \\ University of KwaZulu-Natal, 75 Central Park West 11A, New York, NY 10023, USA \\ viamicizia@yahoo.com
}

\section{Introduction}

The question of language ownership is most relevant in multilingual societies which are characterised by power imbalances among speakers of different languages. Bourdieu (1991, 1997) has argued that verbal exchanges take place in inequitable "linguistic markets" where speech acts are assigned different symbolic values. Within any sociolinguistic community, certain ways of using language are considered "proper", "educated", "standard" or "legitimate", while others are not. According to Bourdieu, "legitimacy" is determined not so much by intrinsically superior linguistic features, but by power relations: the language of the elite is imposed as the norm and functions as a gate-keeper. Mastery of this language is a precondition for claiming symbolic and material resources. One could even argue that, while overt racism is becoming less acceptable in democratic societies, linguicism, or discrimination based on language (Phillipson 1991), continues to reign undisturbed as an alleged "politically correct" mechanism for re(producing) social stratification (Parmegiani 2006a).

South Africa's linguistic market is particularly inequitable. In theory, all eleven official languages are granted the same rights under the post-apartheid constitution; however, in 
reality, the mastery of English is often a precondition for employment, academic success, and political participation. According to Census 2000, only $9 \%$ of the people living in South Africa declared English as their home language.

Language rights activists in South Africa are well aware of this situation and have sought to make this country's linguistic market more equitable by pushing for a greater use of African languages in education and in other domains that open up opportunities for socio-economic empowerment. Often, these activists have juxtaposed English to the "own language" of the majority of the people in South Africa (cf. Zandile 1997; Alexander 2000, 2002, 2003; Heugh 2000; Finlayson 2002; Nicol 2004), creating a dichotomy between English and African languages based on a conception of language ownership that relies very heavily on the notion of mother tongue.

The intention behind the use of this dichotomy on the part of language rights activists is most laudable: promoting equality among South Africa's official languages in order to promote equality among their native speakers. Given the dominance of English and the marginal role played by African languages in prestigious sociolinguistic domains, there is certainly the need to push for the implementation of policies aimed at redressing power imbalances among South Africa's official languages. One should be very cautious, however, in making statements that construct language ownership as a native speaker's prerogative.

The consequences of not being able to claim full ownership of English in a linguistic market such as that of South Africa are not difficult to see: people who can claim English by birthright have a much better chance to succeed in the competition for economic goods and status than those who come to master English as an additional language. For example, when applying for jobs that require "very good English skills" - and most professional jobs in South Africa and other parts of the world these days do - native speakers are likely to have an unfair advantage if they are considered to be the sole legitimate owners of English.

Constructing language ownership exclusively in terms of the notion of mother tongue is at the root of what I shall call the "birth right paradigm". Theoretically, this paradigm is problematic because it oversimplifies the relationship between language, power, and identity with 
widespread assumptions that need to be examined. In this paper, I would like to question the following three assumptions:

1. Language ownership is determined by birth.

2. A person's identity is rooted only in his or her mother tongue. Additional languages can be learned and used for specific purposes, but they do not play a significant role in shaping subjectivity.

3. Native speakers of a language have a better command of this language than non-native speakers in any communicative situation.

Ngugi's theory of "Colonisation of the mind", which has had a seminal impact on the way in which language rights activists construct language ownership (cf. Phillipson 1992: 285-288; Zandile 1997: 203; Alexander 2003: 15), explicitly constructs a person's "own language" as part of a fixed identity core that is established by birth once and for all (Ngugi 1981: 1-12). After claiming that "no man or woman can choose their biological nationality", he argues that, if a person is born African, it is only through an African language that he or she can express his or her personal and cultural identity. Similarly, Skutnabb-Kangas, one of the most prominent figures in linguistic human rights activism, writes - without providing any empirical evidence - that -

Many bilinguals testify to the fact that their second language, which they learnt later in life, feels colder, more alien, less rich in words, less subtle and on the whole poorer. It does not go as deep, it does not come as close to them, it does not affect them as strongly as the first. It feels more superficial, more 'stuck on', it does not awaken the same deep layers of the personality. One is more oneself one's mother tongue. All this seems also to be true of many bilinguals who know their second language very well, just as well, or in many cases, even better, than the language they learned first

(Skutnabb-Kangas 1981: 50)

While many multilingual speakers may indeed agree with Skutnabb-Kangas's assertions, others may not. Therefore, it is important to open up for scrutiny assumptions about language ownership. Epistemologically, the birth right paradigm might not do justice to the 
multilingual complexity of countries such as South Africa. If we think of ownership in terms of identification, we must remember that South Africa is an extremely multilingual country, where people, especially in urban areas, find it difficult to define themselves in terms of just one language (De Klerk 2002: 38; Mesthrie 2002: 12). Rather than owning a mother tongue, they own an extensive and intricate repertoire of languages, dialects, and registers. If we think of ownership in terms of the command of a language, the idea that only native speakers really own English in South Africa is even easier to dispute. Structurally, non-native varieties might differ from the standard set by most white South Africans who use English as their first language. This discrepancy, however, is not necessarily symptomatic of a linguistic deficit (cf. Kachru 1986; Canagarajah 1999; Brutt-Griffler 2002; Mazrui 2004).

Politically, it is even more important to challenge the birth right paradigm than to do so from an epistemological point of view. Peirce (1995) has argued that speakers invest in the process of appropriating an additional language in order to have a return in terms of symbolic and material resources. Seeing language ownership as determined exclusively or primarily by birth right limits the material and symbolic return on investment: no matter how well a person might come to master an additional language, he or she will still be placed in an inferior position with respect to a native speaker. Hence, reifying the birth right paradigm by implying that English cannot be the own language of those who do not inherit it as their mother tongue reinforces the linguicist effects of the use of English as a lingua franca. Rather than supporting this paradigm, language rights activists should reconceptualise language ownership in order to make linguistic markets more equitable. A more inclusive understanding of language ownership, based on the premise that additional languages can be fully appropriated by people who have learned them effectively, can strip dominant languages of their gate-keeping effects. Also, as we shall see, promoting a more inclusive understanding of language ownership can be a way to build consent around policies aimed at increasing the market value of marginalised languages.

\section{Beyond the birth right paradigm: A different theoretical perspective}

The most useful theoretical input for my reconceptualisation of language ownership in terms of an appropriation model (presented more fully in Parmegiani (2006b)), comes from the work of Rampton (1990). The notion of language ownership means different things to 
different people, but generally, when a person says that a language is his or her own language, he or she is making a statement about the role this language plays in his or her identity construction and about his or her perceived level of command of this language. Rampton (1990) has captured these two aspects of ownership with the concepts of "expertise" and "loyalty". Expertise is indicative of the level of command a speaker has of a language. Expertise has a series of advantages over "nativeness" as an indicator of language command:

1. Although they often do, experts do not have to feel close to what they know about: expertise is different from identification.

2. Expertise is learned, not fixed or innate.

3. Expertise is relative; one person's expert is another person's fool.

4. Expertise is partial: people can be experts in several fields, but they are never omniscient.

5. To achieve expertise, one goes through processes of certification in which one is judged by other people. Their standards of assessment can be reviewed and disputed. There is also a healthy tradition of challenging experts.

(Rampton 1990: 99)

The notion of loyalty complements the notion of expertise with the identity aspect of language ownership. According to Rampton (1990: 99-100), loyalty is determined by the interplay of both inheritance and affiliation factors. Inheritance refers to whether or not a speaker is born into the social group traditionally associated with a language; affiliation refers to a speaker's desire to be associated with a language. Again, unlike the notion of mother tongue, these terms do not construe identification with language in fixed, monolithic, univocal terms, but rather as the result of the tension between structural (inheritance) and agentive (loyalty) forces that create a fluid relationship between language, power, and identity that is constantly being negotiated and redefined.

To complement Rampton's contribution, it is important to look at ownership not only from a micro-perspective (the extent to which an individual speaker sees a language as his or her own), but also from a macro-perspective, by looking at which sociolinguistic groups are seen as the legitimate owners of a language in a linguistic market. The works of Kachru (1986), Canagarajah (1999), Brutt-Griffler (2002), and Mazrui (2004) have dealt with this question by 
showing that the macro-ownership of English is becoming increasingly de-centered, and contested. In Africa, South Asia, and other parts of the world, there are now Anglophone communities that have appropriated English, creating national standards that are increasingly being seen as legitimate, and in some cases more appropriate than the standards used in countries such as the United Kingdom and the United States.

\section{Exploring language ownership empirically: Rationale and methodology}

There are several reasons why it is important to carry out empirical research as part of my quest for a deeper understanding of language ownership. Like Canagarajah (2005), I believe that it is crucial to highlight "insider's perspectives" when theorising about language and empowerment. This is crucial in South Africa, where language rights activists have lamented the fact that native speakers of African languages have shown a greater desire to appropriate English than to see a greater use of African languages in domains of power (cf. Heugh 2002; Alexander 2003; De Kadt 2005; Young 2005). Alexander (2000) has drawn on Marxist theory to dismiss this contradiction as a case of either elitism or false consciousness; others have pointed out that, given the hegemonic power of English, native speakers of other languages do not have a choice (cf. Phillipson 1992; Heugh 2000). I certainly do not want to deny the existence of mechanisms such as "false consciousness" and "hegemony" as factors that allow the production and reproduction of inequitable power relations, but I would like to argue that these concepts should be used with extreme caution.

Epistemologically, dismissing empirical evidence that runs counter to our theories using notions such as "false consciousness", "hegemony", or "colonisation of the mind" can hamper the creation of more effective theories of empowerment. Rather than being easily dismissed, the dissonances between our theories and the voices of the people we are theorising about should be the starting point for rethinking our advocacy strategies in order to make language rights activism more effective.

Politically, denying agency to the people we are trying to empower implies that we know what is best for them, and that they do not. This sort of stance is obviously very dangerous, especially when trying to promote marginalised languages in South Africa (Parmegiani 2004). The apartheid government justified the imposition of unpopular language policies with the 
argument that black South Africans were not capable of making decisions in their own interests (cf. Butler 1985; Rose and Tumner 1995). These policies sought to promote African languages and restrict access to English by claiming that the use of a "European" language posed a threat to an essentialised notion of African identity. Hence, language rights activism should stay clear of rhetorical statements that carry echoes of the old regime, but rather get a better understanding of the "insider's perspective" by paying closer attention to the attitudes of native speakers of marginalised languages.

The opportunity to explore language ownership from the insider's perspective came with an invitation to spend a semester as a visiting lecturer at the University of Kwa-Zulu Natal (UKZN). During this appointment, I carried out empirical research with students who had entered UKZN through the Access Program, a bridge program aimed at increasing the number of students coming from previously disadvantaged racial groups. This was an ideal site for exploring language ownership and its implications for identity and power relations for several reasons. Access students do not have the necessary requirements to enter UKZN through the regular admission procedures, but are admitted on the basis of their potential for academic success revealed by their above-average matriculation scores. The vast majority of these students would not be considered native English speakers according to the birth right paradigm, as they come from sociolinguistic communities that are associated with Bantu languages. For these students, appropriating the dominant language has been a precondition for being able to show their potential as learners and to enter the gates of tertiary education. Also, in order to be eligible for this program, Access students need to have attended schools that have been deemed "disadvantaged" by the South African Department of Education. These are generally schools that were reserved for "non-white" racial groups during apartheid.

The present study comprised both a quantitative and a qualitative component (cf. Nunan 1992; Johnstone 2002; Dornyei 2003; Seideman 2005). The quantitative component was based on a questionnaire completed by 120 black South African ${ }^{1}$ students which comprised approximately 40 multiple choice questions aimed at investigating students' language practices and attitudes towards language ownership and empowerment. The findings based on the questionnaire data are discussed in Parmegiani (forthcoming). In this paper, I will present findings related to the preliminary analysis of the in-depth interviews that I carried out with a focus group as part of my qualitative exploration. 
The qualitative component began with ethnographic observations that I collected by interacting with a group of twenty-five Access students as a participant observer in two courses that are closely related to my field of study, namely English Language Development, which focuses on grammar and vocabulary building, and Academic Literacy, which focuses on the composition principles that shape academic writing genres.

During the semester, I had the opportunity to move very quickly from a position of silent observer, whose presence was hardly acknowledged by the students, to the position of an active participant in the learning process who contributed to discussions with questions and who was often invited, by both the students and the two instructors, to relate his own life experience in conversation in terms of the topics that were being discussed. My impression was that, once they had overcome their initial intimidation, students found my subject position both reassuring and intriguing. As a man who is originally from Italy but who is based in the United States, I generated a lot of interest among students who had never left South Africa and who had a strong desire to travel and see the world. Many of them had had little contact with people from overseas and they seemed eager to travel vicariously by getting to know me. Like Rudwick (2006, 2008), I found that being white, but not South African, made it easier to engage in conversations about language, power, and identity, which in a country like South Africa cannot be divorced from the issue of race. It has also been my experience that being a non-native English speaker may have helped create more common ground between myself and the students. The fact that speaking English as an additional language did not stop me from becoming an English lecturer in the United States probably also helped students to identify with me. Most importantly, however, I believe it was my love for South Africa and my genuine desire to explore the students' ways of thinking that made it possible for me to be granted access to their discursive universe in a relatively brief period of time.

The interviews were carried out shortly before the end of the term (cf. Dunbar, Rodriguez and Parker 2002; Fontana 2002; Platt 2002; Ryen 2002). During the interviews, I sought to engage students in conversations about language, identity, and power relations in the context of their lives and the realities of South Africa's linguistic market. My goal was to explore some of the discourses that lie behind the questionnaire data. I was particularly interested in delving into the following questions: 
1. What are the discourses students use to claim and/or reject the micro-ownership of the languages in their repertoires?

2. Where do these discourses place students in the continuum between the birth right and the appropriation model?

3. What role do fundamental dimensions of language ownership such as affiliation and expertise play in these discourses?

In the first round of interviews, I drew on life history and in-depth techniques in order to allow meta-discourses to emerge from students' life narratives (Johnson 2002). In the second round of interviews, I drew on stimulated recall techniques (Nunan 1992), by asking students to delve into some of the statements they had made in the previous interviews and in their responses to the questionnaire.

The six students who participated in the focus group were selected according to a number of criteria. First, I selected those students who seemed most eager to engage in discourses about language ownership. Among these, I looked for a group of students who would represent the broadest possible spectrum of views on my research topic. I also sought to maximise diversity in terms of sociolinguistic background, paying particular attention to factors such as racial and linguistic characteristics of the schools students attended and the type of community where students grew up. Finally, to ensure an equal gender breakdown, three female and three male participants were selected.

In the preliminary analysis of the data presented below, I will begin by reporting key findings about attitudes towards micro-ownership and macro-ownership that emerged from the questionnaire. Then I will delve into the significance of these findings by analysing the discourses of three of the students in the focus group in which they claim or reject the ownership of English, both at the micro and at the macro level. 


\section{Attitudes toward language ownership}

\subsection{Attitudes towards micro-ownership}

Of all the 120 students who completed the questionnaire, $72 \%$ do not regard English as their own language, while $28 \%$ do. Xolela is a male student who rejects the micro-ownership of English. The interview extract in (1) illustrates the essence of his argument.

(1) I: What does it mean to say that a language is your own language?

$\mathrm{X}$ : To me it means that it is the language that was given by my parents. It's the language of my mother that she breastfeeded [sic] me.

I: $\quad$ Do you think it's possible to own more than one language?

$\mathrm{X}$ : It is not possible to have more than one language, because I am a Zulu speaker. The Zulu language is mine because I learned it from the day I started speaking. That was the language I was opened to. It will be impossible to say I own another language, like English for example.

I: What if you don't want to be defined by just one language?

X: You lost your identity. You don't know who you are any more.

I: Maybe you get another identity through another language ...

X: $\quad$ But the accent. It's not your mother tongue. You can learn a language and be fluent in it, but you can't gain an English accent, because you are not English.

I: What if you parents send you to a model $\mathrm{C}$ school and you end up sounding just like a native English speaker?

X: Hey, I would hate myself. Seriously, I would hate myself. And I would probably question my parents for it once I grow up.

Xolela's construction of micro-ownership is based on the fundamental assumptions of the birth right paradigm exposed earlier in this paper: a person can only really own his or her mother tongue; language ownership is determined by birth; a person's identity is rooted only in his or her mother tongue. According to this view, it is not possible to own more than one language because there needs to be a one-to-one correlation between language and identity, and only the mother tongue, as an essential marker of ethnicity (Rudwick 2008), can be part of this correlation. Blurring ethnolinguistic boundaries by allowing additional languages to be part of a person's identity construction results in a loss - rather than a redefinition - of 
identity. Accents protect these boundaries, but if one trespasses, for example by appropriating an accent that makes an additional language speaker sound like a native speaker, there would be cause for self-hatred.

Like Xolela, April (a female student) takes her mother tongue isiZulu as the starting point of her construction of micro-ownership, but she is just as vocal in staking her claim to English as she is in staking her claim to isiZulu, as reflected in the extract in (2).

(2) No one can come to me and say something in English that I wouldn't understand. I know most of the things in English, and I am able to understand people whenever they speak, in the news and everywhere. I can write it. I can speak it. It's part of me know. Even though I know my Zulu, but I know my English as well. So it's like, my English and my Zulu.

It is through her expertise that April claims ownership of her additional language. This means that the causal relationship between expertise and affiliation in April's construction is antithetical to Xolela's. For April, having been able to appropriate expertise in English has had an impact on her language affiliations. Because she owns English in terms of command, she has come to own it in terms of identity too. For Xolela, language affiliation, which is determined by birth once and for all, precludes the possibility of fully owning an additional language in terms of expertise. While he admires Thabo Mbeki's command of English, which he describes as perfect, he sees the president's English as being inferior to the English of a hypothetical native speaker, because for a native speaker, "English is his own language", while for the president, it is not.

Prosperity is a female student who goes even further in questioning the birth right paradigm by pointing out that "people sound very possessive" when they refer to a language as their own. While acknowledging that people do inherit languages from their parents, she stresses that ownership can be the result of a successful appropriation process that happens later in life (cf. the extract in (3)).

(3) A language has its own indigenous speakers, but what about the other people that are learning that language and wanting to use that language? I think you can say a 
language is yours when you are an indigenous speaker, but you can also say that a language is yours when you have mastered the language, when you are able to speak the language.

\subsection{Attitudes towards macro-ownership}

In order to investigate attitudes towards macro-ownership, I asked students who took the questionnaire to identify the "best speakers" of English in South Africa, choosing from sociolinguistic groups that I had defined in terms of race, mother tongue, and expertise. Most respondents (56\%) believed that anyone who has learned English well can be seen as being among the "best speakers", which suggests that the majority of the sample is open to the idea that English can be appropriated from the point of view of command. However, the perception that English expertise belongs only to white people is widespread, since $23 \%$ of the students see whiteness, in addition to nativeness, as a necessary condition for being considered to be among the best speakers of English in South Africa.

Not surprisingly, Prosperity sees the macro-ownership of English in South Africa as something that can be claimed by anyone who has learned it well. She believes that having a language as a mother tongue endows speakers with a high level of expertise by default; however, she sees a native speaker's expertise as the result of exposure to the language, rather than as the result of a rigid correlation between language and identity (cf. the extract in (4)).

(4) People who speak English at home have a background. They are used to expressing themselves in that language. English is like mathematics. You have to practice it, in order to know it very well. For example, I am a first language Zulu speaker. I have a huge background because I speak it daily. I have a huge vocabulary of isiZulu. The same applies to people who speak English at home.

According to Prosperity, the fact that native speakers are naturally endowed with "a huge background" of their native tongue does not mean that they are the only people entitled to claim ownership of a language on the basis of expertise. Non-native speakers have to go out of their way to appropriate an additional language, but they can do it, and they can even get to the point where they can outperform native speakers (cf. the extract in (5)). 
(5) English is part of me because I strived hard in mastering it, with the help of the teachers, who were teaching it from primary school, and my family. I consider it my language because I strived to learn it a lot ... I can compete with people who speak English at home, because everyday I try to learn new words and to make something out of English.

Unlike Prosperity, April established a racial pecking order in her discourse about the macroownership of English. I found this surprising, given that she, who is a black South African woman, did claim the ownership of English for herself on the basis of her expertise. Her explanation for excluding non-white native English speakers, such as the Indian community, from the group of best English speakers in South Africa, appears in (6).

(6) Oh, the Indians! They don't know how to speak good vocabulary English. I wouldn't say it's the right English. Their English is very different from a white person's English.

I was less surprised to hear Xolela racialise expertise in his discourse about macro-ownership, given the rigid equation that he had drawn between mother tongue, ethnic identity, and expertise (cf. the extract in (7)).

(7) With Indians, what I have seen from high school and even here, they speak English, but they are not best speakers. Their accent is not English. There is an Indian language influence, so they use words incorrectly, like "come quickly quickly". White people don't do this.

What I found most concerning but also eye opening in Xolela's discourse, was how restricting the ownership of the dominant language on the basis of race can degenerate into racial discrimination in the work place (cf. the extract in (8)).

(8) Even the lecturers, Indian lecturers, they speak faster than English speakers, so they confuse us, and we chose to have white English speaking lecturers rather than Indian, because we don't understand Indian lecturers. 


\section{Conclusions: Opening up language ownership for debate in South Africa}

The discourses I have examined so far confirm that the issue of language ownership has important implications for identity construction and power relations. Language rights activists, both locally and internationally, are very aware of this and have sought to fight the hegemony of dominant languages such as English in order to affirm identities rooted in marginalised languages and to make native speakers of those languages less dependent on English for their socio-economic empowerment (cf. Zandile 1997; Alexander 2000, 2002, 2003; Heugh 2000; Finlayson 2002; Nicol 2004). In South Africa, activists have often juxtaposed English to the "own language" of the majority of the people because English is spoken as a mother tongue by only approximately $9 \%$ of the country's population. I have argued that precluding non-native speakers from the possibility of claiming ownership of the dominant language is problematic, and I have suggested an alternative model for conceptualising language ownership, a model based on the assumptions that (i) additional languages can be fully appropriated, and (ii) language allegiances do not need to be mutually exclusive. I have also discussed the preliminary findings of an empirical study carried out at the university of KwaZulu-Natal investigating attitudes towards language ownership among black South African students who received their secondary education in disadvantaged schools. I have presented two key findings on the basis of discourses collected in a series of in-depth interviews, analysing discourses that fall into what I have called "the birth right paradigm" and discourses that are closer to what I have called the "appropriation model".

My empirical exploration of language ownership was driven by what I see as the epistemological and political need to pay closer attention to the voices of the stakeholders when theorising about language, empowerment and identity. Hence, it would be hypocritical of me to dismiss the voices of Xolela and of $72 \%$ of the students in the sample who do not see English as one of their own languages by suggesting that they should. I believe that people should have maximum freedom in constructing themselves. After all, is empowerment not, at least to some extent, about people being able to be what they want to be? It is precisely this belief that made me look for more fluid, de-centered ways of looking at languages as markers of identity and as tools for negotiating power relations. This is why I argue that it is important to open up the concept of language ownership for discussion. 
While it is important to respect speakers who choose to see only their mother tongue as their own language, it is just as important to respect those who choose to claim ownership of English as additional language. Unfortunately, this does not always happen. As Rudwick has pointed out, for black South Africans, taking ownership of English as an additional language can result in being called a "coconut", a racial slur that is used to point fingers at people of colour who are perceived as trying to "act white". Most of the students I interviewed mentioned in the narratives of their struggle to appropriate English incidents where they were subjected to this epithet. These incidents did not leave the students with a sense of selfempowerment.

Xolela's sweeping generalisations about the way in which Indian lecturers and white lecturers use English illustrate the linguicist potential of constructing language ownership on the basis of a rigid equation between language of inheritance and identity. If we put race and ethnicity into this equation, like Xolela did and many other South Africans would, the links between racism and linguicism become clear. In a job market where virtually all professional positions require " good English skills" it would not be that difficult to use language as a proxy for race, if the legitimate ownership of English is restricted to white native speakers.

Ironically, seeing English ownership as a native speaker's prerogative might also be an obstacle for the promotion of African languages. Given the fact that English is a precondition for professional employment, it is not surprising that native speakers of African languages are more concerned with appropriating the highest possible level of English expertise than in increasing the market value of their mother tongues. It is true that if this value were increased, South Africa's linguistic market would be more equitable and English would not have the same gate-keeping effects. This is precisely the goal of language rights activism. The assumptions about language, power and identity of the birth right paradigm, however, do not help achieve this goal. If the legitimate ownership of English, and consequently expertise in this language, is conceived of as a native speaker's prerogative, we should not be surprised to see native speakers of African languages resisting mother tongue instruction and going out of their way to send their children to monolingual English medium schools in order to make them as "native" in English as possible. If activists argue that English ownership can be claimed by anyone as the result of a successful learning process, and if they can convince the general public that the best way to learn an additional language is by building on the mother 
tongue, it might be easier for black South Africans to see that appropriating the power of English does not entail disowning or marginalising any other language spoken in the country.

\section{Notes}

1. I use the term "black" to refer to the indigenous population of Southern African that is associated with Bantu languages and that were referred to as "African" during apartheid.

\section{References}

Alexander, N. 2000. English unassailable but unattainable: The dilemma of language policy in South African Education. PRAESA Occasional Papers 3. Cape Town: PRAESA.

Alexander, N. 2002. Linguistic rights, language planning and democracy in post-apartheid South Africa. In S. Baker (ed). Language policy: Lessons from global models. Monterey Institute of International Studies. pp. 116-129.

Alexander, N. 2003. The African Renaissance and the use of African languages in tertiary Education. PRAESA Occasional Paspers 13. Cape Town: PRAESA.

Bourdieu, P. 1991. Language and symbolic power. Cambridge: Harvard University Press.

Bourdieu, P. 1997. The economics of linguistic exchanges. Social Science Information 16: 645-668.

Brutt-Griffler, J. 2002. World English. A study of its development. Clevedon, etc.: Multilingual Matters.

Butler G. 1985. English and the English in the new South Africa. English Accademy Review 3: $162-175$.

Canagarajah, S. 1999. Resisting Linguistic Imperialism. Oxford: Oxford University Press.

Canagarjah, S. 2005. Ethnographic methods in language policy. In T. Ricento (ed). An introduction to language policy. Malden: Blackwell. pp. 153-169.

Central Statistics Bureau. 2000. Census 2000. Pretoria.

De Kadt, J. 2005. Language development in South Africa: Past and present. Southern African Linguistics and Applied Language Studies 23(1): 92-110.

Dornyei, Z. 2003. Questionnaires in second language research. Construction, administration, and processing. Mahwah and London: Erlbaum 
Dunbar C., D. Rodrigues and L. Parker 2002. Race, subjectivity and the interview process. In J. Gubrin and J. Holstein (eds). Handbook of interview research. Thousand Oaks, etc.: Sage. pp. 279-297.

Finlayson, R. 2002. Multilingual power. In This Day, 2 February 2002.

Fontana, A. 2002. Postmodern trends in interviewing. In J. Gubrin and J. Holstein (eds). Handbook of interview research. Thousand Oaks, etc.: Sage. 161-175.

Heugh, K. 2000. The case against bilingual and multilingual education. PRAESA Occasional Papers 6. Cape Town: PRAESA.

Heugh, K. 2002. A history of mother tongue and bilingual education in South Africa. In T. Bekett (ed). Reports on mother tongue education with special reference to South Africa and Belgium. International workshop of the Universities of Cape Town and Antwerp. Cape Town: PRAESA. pp.11-22.

Johnson, J. 2002. In-depth interviewing. In J.Gubrin and J. Holstein (eds). Handbook of interview research. Thousand Oaks, etc.: Sage. 103-119.

Johnstone, B. 2000. Qualitative methods in sociolinguistics. New York and Oxford: Oxford University Press.

Kachru, B. 1986. The alchemy of English: The spread, functions, models of non-native Englishes. Oxford: Pergamon Press.

Mazrui, A. 2004. English in Africa after the cold war. Clevedon, etc.: Multilingual Matters.

Mesthrie, R. 2002. South Africa: A sociolinguistic overview. In R. Mesthrie (ed). Language in South Africa. Cambridge: Cambridge University Press. pp. 10-25.

Nuan, D. 1992. Research methods in language learning. Cambridge: Cambridge University Press.

Parmegiani, A. 2004. The ambivalent power dimension of English: Some implications for pedagogy and multilingualism advocacy. Paper presented at the Conference of the Southern African Applied Linguistics Association, Pietersburg, South Africa.

Parmegiani A. 2006a. On race, language, power and identity: Understanding the intricacies through multicultural communication, language policies and the Ebonics debate. TESOL Quarterly 40: 641-649.

Parmegiani A. 2006b. Claiming the power of English in South Africa: From a "birthright" to an "appropriation" model for understanding English ownership. Paper presented at the Conference of the Southern African Applied Linguistics Association, Durban, South Africa. 
Parmegiani, A. (forthcoming). Reconceptualizing language ownership. A case study of language practices and attitudes among students at the University of KwaZulu-Natal. The Language Learning Journal.

Peirce, B. 1995. Social identity, investment, and language learning. TESOL Quarterly 29: 931.

Phillipson, R. 1992. Linguistic imperialism. Oxford: Oxford University Press.

Platt, J. 2002. The history of the interview. In J. Gubrin and J. Holstein (eds). Handbook of interview research. Thousand Oaks, etc.: Sage. pp. 33-101.

Rampton, M. 1990. Displacing the native speaker: Expertise, affiliation, and inheritance. ELT Journal 44(2): 97-110.

Rose, B. and R. Tunmer. 1975. Documents in South African Education. Johannesburg: Donker Publishers.

Ryen, A. 2002. Cross cultural interviewing. In J. Gubrin and J. Holstein (eds). Handbook of interview research. Thousand Oaks etc.: Sage. pp. 335-355.

Rudwick, S. 2006. Language, identity and ethnicity in post-Apartheid South Africa: the case of the isiZulu community. Doctoral dissertation, University of KwaZulu-Natal.

Rudwick, S. 2008. "Coconuts" and "Oreos": English speaking Zulu people in a South African Township. World Englishes 27(1): 101-116.

Seideman, I. 2005. Interviewing as qualitative research. New York: Teacher's College Press.

Skutnabb-Kangas, T. 1981. Bilingualism or not? Avon: Multilingual Matters

Zandile, N. 1997. An analysis of educational challenges in the new South Africa. Lanham: University of America Press. 